\title{
Impact of current expected credit loss (CECL) on the US financial institutions - An overview
}

\author{
Mohini Yadav \\ Assistant Professor, Sri Venkateswara College, University of Delhi, India \\ *Corresponding Author: Mohini Yadav \\ Email: mohini.yadav@svc.ac.in
}

\begin{abstract}
Failure in the timely adjustment of the reserve levels based on reasonable anticipation of future conditions was turned out to be the major drawback of the Allowance for Loan and Lease Losses (ALLL) accounting standard during the great recession of 2007-2008. ${ }^{1}$ The major issue during the time of crisis was that the unfavorable economic conditions was not taken into consideration for the calculations of losses under the ALLL method. Because of that reserves were not adjusted for the expected losses in the future. In 2011, The OCC (Office of the Comptroller of the Currency) and Fed (US Federal Reserve) anticipated that the allowances in the industry would increase by $30 \%$ to $50 \%{ }^{2}$ But since the expectations of the economy has changed drastically since then, many economist have predicted that the increase in the industry allowances would not be significant. Keefe, Bruyette \& Woods, Inc., an investment banking firm headquartered in New York City predicted in September 2015 that the median increase in ALLL for small and mid-size bank will be meagre $3 \% .^{2}$

After the great recession, Financial Accounting Standards Board (FASB) reviewed how financial institutions are estimating the losses in the ALLL calculation. Various weaknesses in the existing incurred loss model (ALLL) were exposed, which included complexity and delay in recognition of credit losses. At the time of review, The FASB and the International Accounting Standards Board (IASB) discussed and proposed many approaches to correct the damage. Ultimately the final resolution was to make a new accounting standard altogether that should accelerate recognition of credit losses and CECL come into the picture. CECL requires the estimation of expected losses over the life of the loans, and is forward looking approach to make the allowances by giving consideration to the future economic outlooks and the life of the loan. The major expectation of the FASB while introducing this new standard - CECL is that it will improve the liquidity, stability and financial reporting of the financial institutions, and will necessitate the timey recording of credit losses on loans.

After much discussions and review, the Financial Accounting Standards Board finally issued 'Measurement of Credit Losses on Financial Instruments' in June $2016,{ }^{3}$ which contained the methodology for the current expected credit losses (CECL) for estimating allowances for credit losses loans and other financial instruments. As per the CECL methodology, financial institutions requires a determination of the expected amount to be collected on a portfolio of originated loans from day one till the entire life of the loan. The day one CECL allowance would be equal to the difference between the originated loan amount and expected loan amount to be collected over the life of the loan.
\end{abstract}

Keywords: CECL, Current expected credit loss, ALLL, Allowance for loan and lease losses, Significant of CECL, Challenges of CECL, Implementation of CECL.

\section{Objective of the Study}

The objective of writing this paper is to understand and analyze the impact of the new accounting standard issued by FASB in place of ALLL in the US. We are interested in exploring the extent to which this new accounting standard will have an impact on the US affected institutions, it' simple mentation requirements, deadlines and it's attached importance and challenges for the institutions and industry as a whole.

\section{Concept of CECL}

Current expected credit loss (CECL) is a new accounting standard that is recently proposed to change the recording system of expected credit losses by the financial institutions in place of ALLL. All institutions which are involved in issuing credit are covered under FASB's CECL standards banks, credit unions, financial institutions and holding companies filing under GAAP (Generally Accepted Accounting Principles) accounting standards, whether public or private, regardless of size. ${ }^{4}$

Post financial crisis, the urgent requirement was to recapitalize the financial institutions and to restore the economy. Supervisory authorities and the regulators were working towards guarding the financial institutions against systemic risk, with an increased emphasis on stress testing. A stress testing in a bank is an analysis or simulation conducted under hypothetical unfavorable economic scenarios which are unfavorable, like recession or market crisis, in order to determine whether a bank has sufficient capital to withstand the impact. At the time of crises, revolutionary changes to ALLL accounting standards were warranted in order to better regulate and determine the appropriate level of reserves for credit losses in the balance sheets.

Accounting for loan losses is the most important calculation of the bank accounting system, as it actually affects the working of banks i.e. lending money and collecting principal and interest. In the current ALLL model, the banks record those amounts which they do not expect to collect in the future in the allowance for loan and lease losses (ALLL).So, any additions to the ALLL is recorded as an expenses that reduces the bank capital.

International financial reporting standard (IFRS) 9 standard (deals with financial instruments) published two years earlier, is different with US-CECL standard in many significant ways, though they share an important feature i.e. the calculation of the expected credit loss is now computed over the life of the loan. ${ }^{4}$ Many analysts have already commented that the older method for computing expected 
credit losses drastically underrepresented impairments and the calculation of potential future losses, which can now be corrected with the help of CECL method. ${ }^{4}$

\section{Importance of CECL}

CECL is widely recognized as the most significant accounting change in the last 40 years and is expected to have a magnificent impact on the banking functions. ${ }^{5}$ The CECL method in addition to bring the reserve levels at the appropriate level, it will also bring transparency in accessing the health of the institution. Current ALLL model is backward looking, for example, if in the past $15 \%$ of the loans with certain attributes are defaulted then it will be assumed that this trend will continue and only $15 \%$ of the loans outstanding will be transferred to their loss reserves, which is not an always right ${ }^{6}$. Increased reserves for the loan loss represent the largest impacts to balance sheets under various economic scenarios, and it is expected that this new accounting standard changes will possibly well through future stress tests as well.

Conceptually, CECL standard will affect the calculations of credit loss reserves, but it also analyze how financial institutions manage their allowance for loan and lease losses and organizational processes. There are no fixed guidelines regarding the scope of these changes as it is highly dependent upon the complexity of the respective entity's balance sheet. Current credit loss accounting standards have been in place for about 40 years ${ }^{7}$ and moving to a new model is difficult for the existing entities. If we compare the two models theoretically, ALLL essentially reflects the current losses in a portfolio, whereas CECL reflects the current risk in the portfolio, risk includes both current and future credit losses. Impairment to the loan in the earlier model is normally measured in pools of originated loans and is heavily based on historic data of annual loss rates. In contrast, CECL relies on the historical data that is not annual loss rates, but on life of the loan.

\section{CECL Challenges}

There is always a sense of fear to move from a known notion to an unknown new notion. CECL is bringing lots of notable advantages from the previous method as it is expected to increase the stability and liquidity in the system but these changes are also bringing challenges to the current entities. Shift from practices under FAS-5 (Accounting for Contingencies) and FAS-114 (Accounting by Creditors for Impairment of a Loan) is not easy as it appears on papers. There are lot of requirements which have to be adhere by the institutions within the prescribed time frame. Current rules require an allowance for loan losses only expected to incur over a year, while CECL eliminates the probable loss threshold and takes into consideration a lifetime loan loss allowance which has to be established on very first day itself ${ }^{6}$. This is definitely going to bring a lot of volatility in the bank's earning and profitability.

Currently, ALLL requires the maintenance of only historical data on credit losses, but CECL will require maintenance of exhaustive data with additional granularity.
But the major problem is that many institutions are struggling with insufficient data which is required to estimate lifetime loan losses. In addition to historical data, macroeconomic level data and risk influencers will also be given due weightage in the analysis to assess the impact of various economic scenarios on credit losses. Financial institutions have to face another potentially significant challenge in terms of how they forecast losses over the full life of the asset as the current method only apply forecasts over a horizon determined over a loss emergence period. CECL will also necessitate increased transparency in the assumptions settings, its applications and in the full disclosures around the estimates of allowance.

CECL standards are principles-based, and not prescriptive as to how institutions address specific modeling challenges. There is flexibility in how they can overcome the challenge and decide the most suitable method.

\section{Implementation of CECL}

FASB has set deadlines for the adoption and implementation of the CECL standard for different entity wise. The loan allowance process to be used by the entities also affects other tasks, like stress testing and capital planning. Financial institutions are required to design the model in such a way as to avoid any of the complexities in understating and using the process. Another major point entities have to consider is that the calculations involved in the CECL method is more exhaustive and requires a much deeper level of analysis, modeling and reporting than what has previously been required. It is tough for them as entities usually wants to refrain from designing processes and systems again and again.

The financial institutions will now need to recognize that transition to CECL method is significant and proper planning and management is required. They have to make plans for each individual task required in the transition that includes additional capacity of their model execution platforms. Many institutions are considering whether they should take the services of third party vendor in order to implement with this new accounting standard. As per the survey conducted by PKM's, around 45 percent of respondents were setting up with the third party vendor. ${ }^{7}$

\section{CECL Deadlines ${ }^{8}$}

1. Deadline for Public business entities that are SEC filers is set for fiscal years beginning after December 15, 2019.

2. For all other public business entities, deadline is set for fiscal years beginning after December 15, 2020.

3. Entities which are not public business entities, deadline is set for fiscal years beginning after December 15, 2021. Early adoption is also permitted for all entities for fiscal years beginning after December 15, 2018.

Conflict of Interest: None. 


\section{References}

1. Kevin Guckian, Anna Krayn, Emil Lopez, CECL: Implications and Approaches to Implementation, GARP Webcast Series, September, 2016, Available from https://www.moodysanalytics.com//media/presentation/2016/the-long-road-to-ceclimplementation-considerations-slides.pdf

2. American Bankers Association, FASB's Current Expected Credit Loss Model for Credit Loss, Accounting (CECL): Background and FAQ's for Bankers, June, 2016, Available from

https://www.aba.com/Advocacy/Issues/Documents/CECLbackgrounder.pdf

3. FASB, FASB Accounting standard update, Financial Instruments - Credit Losses (Topic 326), No. 2016-13, Measurement of Credit Losses on Financial Instruments, June, 2016, Available from https://www.fasb.org/jsp/FASB/Document_C/DocumentPage? cid $=1176168232528 \&$ acceptedDisclaimer $=$ true

4. Tom Kimne, CECL: Are US banks ready?, Available from https://www.sas.com/en_us/insights/articles/risk-fraud/ceclare-us-banks-ready.html

5. The Oakleaf Group, Leveraging stress testing processes and systems, Available from https://www.theoakleafgroup.com/sites/default/files/u157/CEC L\%20-

$\% 20$ Leveraging\%20Stress\%20Testing\%20Processes\%20and $\%$ 20Systems.pdf

6. Anna Krayn, Moody's Analytics, Risk Perspective, The Convergence of Risk, Finance and Accounting: CECL, Vol 8, November, 2016, Available from

https://www.moodysanalytics.com/-/media/article/2016/riskperspectives-finance-accounting-cecl.pdf

7. ABA Banking Journal, CECL Implementation: Where Banks Are Now and Where They Need to Be, July, 2018, Available from https://bankingjournal.aba.com/2018/07/ceclimplementation-where-banks-are-now-and-where-they-needto-be/
8. BDO United States, CECL implementation guidelines, July, 2018, Available from

https://www.bdo.com/insights/industries/fisf/ceclimplementation-guide-(1)/cecl-implementation-guide

9. FASB, FASB issues new guidance on accounting for credit losses, news release, June, 2016, Available from https://www.fasb.org/jsp/FASB/FASBContent_C/NewsPage\& cid $=1176168232900$

10. Federal Deposit Insurance Corporation, Current Expected Credit Losses (CECL), Status Update 2018, FDIC Atlanta Regional Regulatory Conference Call, September, 2018, Available from https://www.fdic.gov/news/conferences/otherevents/2018-0927-atlanta-presentation.pdf

11. Crowe, FASB clarifies CECL non-PBE effective dates; CAQ releases CAMs too, 2018, Available from https://www.crowe.com/insights/financial-institutionsexecutive-briefing/financial-institutions-executive-briefing-815-2018

12. Dr. Cristian deRitis, Dr. Deniz Tudor, CECL's Implications for Bank Profitability, System Stability, and Economic Growth, November, 2016, Available from https://www.moodysanalytics.com/risk-perspectivesmagazine/convergence-risk-finance-accounting-cecl/spotlightcecl/implications-bank-profitability-system-stabilityeconomic-growth

How to cite this article: Yadav M. Impact of current expected credit loss (CECL) on the US financial institutions - An overview. J Manag Res Anal 2019;6(2):85-7. 